\title{
Probing strategy-project alignment: The case of the South African Social Security Agency
}

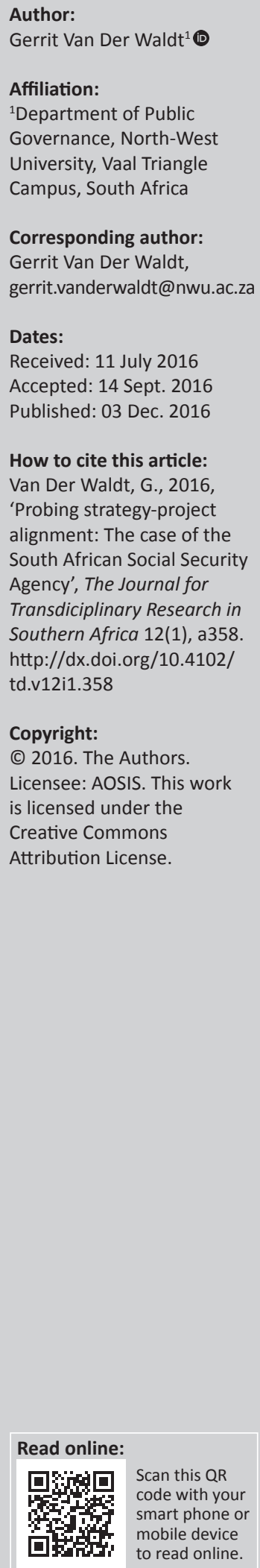

\begin{abstract}
Public institutions, such as the South African Social Security Agency (SASSA) increasingly function in multi-project environments to translate strategies successfully into service-delivery initiatives. However, this 'projectification' often causes projects to be designed and executed haphazardly. This can lead to budget and schedule overruns, and the general wastage of an organisation's resources. Project failures often occur where organisations do not ensure that specific projects are aligned with their core strategies. The purpose of this article is to combine the theories and principles of organisation, management, strategic management, and project management in an effort to pinpoint core determinants that can help establish the extent to which an organisation manages the alignment of its strategic projects. In the present study, the author applied the principles of interdisciplinarity, systems thinking, and organisational integration. The combined core determinants that were uncovered were then used in an empirical investigation of SASSA. The purpose of this investigation is to identify particular challenges the organisation faces in aligning their strategies and projects successfully. Thereafter, a number of recommendations follow to address these challenges.
\end{abstract}

\section{Introduction}

During the first three decades of the 20th century, diverse conceptions developed about organisations as well as the principles and practices of its management. These concepts have been modified significantly to comply with advances in scientific inquiry regarding people (i.e. behavioural theory) and organisations (i.e. systems theory), which led to further postmodern paradigms and notions of management. Organisation and management theories flowing from new empirical investigations can be regarded as eclectic bodies of knowledge, which reflect the diversity of particular settings and the multitude of variables involved.

Traditional wisdom holds that an organisation's strategy is meant to be realised through ongoing activities or functional operations. A modern trend, however, views the proliferation of projects as the main form of temporary organisation intended to execute strategies. Increasingly projects are used as vehicles to implement strategies and have become a topical area of empirical investigation (cf. Hauc \& Kovac 2000). In this regard Shenhar et al. (2001) refer to projects as 'powerful strategic weapons'. However, this 'projectification', if not managed properly, may lead to 'project overload', wastage of organisational resources and, ultimately, distraction from the organisation's strategic goals (DyReyes 2008:2). A global survey in 2004 by the accountancy firm Pricewaterhouse Coopers found that only a handful of projects did achieve project success (Stanleigh 2016). The survey established further that only $2.5 \%$ of global public and private sector organisations attain complete project success. A major reason for project failure is that most organisations do not ensure that the projects they implement are aligned with their core strategies.

Based on the principles of interdisciplinarity, systems thinking and organisational integration, the purpose of this article was to combine the principles of organisation, management, strategic management and project management to help identify core determinants that indicate the extent to which an organisation (i.e. case study) manages the alignment of its strategy projects. These mentioned determinants will then be used to engage participants (i.e. senior managers as units of analysis) in the case study (i.e. the South African Social Security Agency [SASSA]). The aim was to uncover particular challenges that the mentioned organisation (as case study) faces when planning to align its strategies and projects efficiently. Recommendations will then be made to address these challenges.

Schematically, the design of the article as well as the methodological phases that were followed is illustrated in Figure 1. 


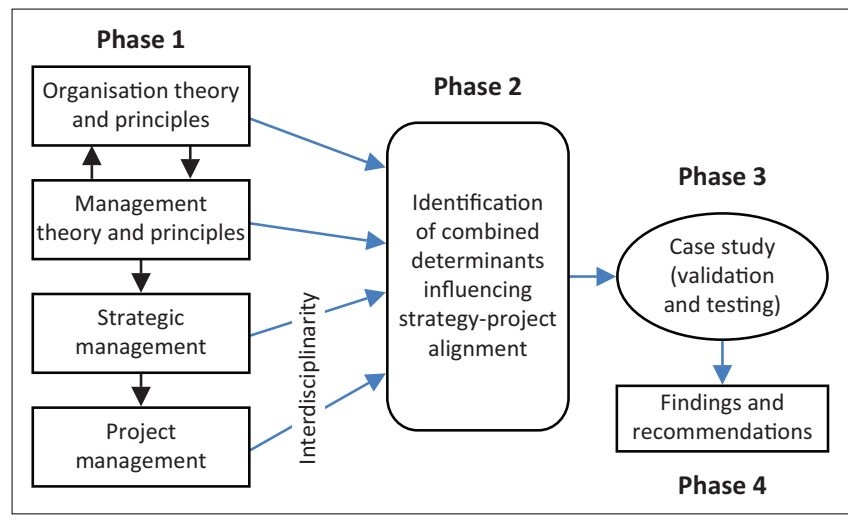

FIGURE 1: Design and phases of the article.

The arrows shown in Figure 1 represent the reciprocal relationship between the key constructs of this article. The effective functioning of organisations depends on sound management, while managers can only perform their functions within in an organisational setup (hence the two-way direction of the vertical arrows for Phase 1). Strategic management and project management can be regarded as specific disciplines or domains within the field of management. Projects are utilised to execute organisational strategies (hence the one-way direction of the vertical arrows to illustrate the hierarchical nature of this relationship). Interdisciplinarity in this context means expanding the boundaries of conventional knowledge domains of individual disciplines (i.e. organisation and management) for the scientific inquiry into a specific topic. This is done by adopting and building on knowledge or methodologies from other disciplines (cf. Kleinberg 2008:11; Van der Waldt 2014:173).

\section{Theory and principles of organisation}

According to Kast and Rosenzweig (1974:6) organisations are goal-directed psychological and technological systems, which function as an integrated whole. Robbins (1990:39) and Luhmann (2013:44) elaborate on this dimension of integration by characterising organisations as 'co-operative systems' that require vertical and horizontal integration and alignment of activities and processes.

Systems theory basically allowed organisational theorists over time to redefine the organisation and the relationship between organisations and the environment in terms of an increasingly complex formula (Fauconnier 1987:100; Luhmann 2013:44). The systems approach to managing organisations emerged in the 1950s as a counterpoint to existing practices that focused on selected aspects and functions of an organisation in isolation (Roth 1992:1). The approach became popular in the 1980s, based on the principle that 'the whole is more than the sum of its parts' (Churchman 1968:29; Mintzberg 1989:223). The systems view approaches the organisation as an integrated system consisting of related subsystems (McNamara 2008; Morgan 1989:48) and functioning within macro-systems (Baker \& Branch 2002:2). To understand the system, one has to determine what an 'organisation does using what inputs, with what resources to achieve what results' (Glans et al. 1968:12). Sylvie and Witherspoon (2002:15) argue that organisations are'pyramidal, hierarchical systems with different functional units, vertical (mostly downward) communication, and management that is predominantly task-focused than employee-centred'. The components within a system are interdependent. Johnson and Schiller (1991:63) and Robbins and Coulter (2005:35) emphasise the fact that this level of interdependence makes coordination and cooperation within an organisation crucial for optimal performance.

According to Churchman (1968:30), an organisation is linked closely to its strategic goals and objectives. Senior management sets these goals, generates strategic plans for the system, allocates resources and controls the system's performance (Churchman 1968:44; Dawson 1993:10-11). Glans et al. (1968:18-20) and Gitlow et al. (2005:3) argue that each step in an organisation can be regarded as a process. A process, in turn, is a collection of interactive systems or components that transform organisational inputs (i.e. resources) into outputs (i.e. services and products) towards a specific aim (Gitlow et al. 2005:3). A process-based approach to the management of an organisation as a system focuses on a multiplicity of micro-subprocesses that fit into a macro-process, working in alignment and synergy (Baker \& Branch 2002:22; Gitlow et al. 2005:3).

Several authors indicate that an organisation consists of both 'hard' and 'soft' factors, and they emphasise the importance of both aspects for the effective performance of organisations (cf. Mobley, Wang \& Fang 2005:12; Westcott 2006:14). Summarising the literature on organisational dynamics, Abel (1999:34) characterises organisations as socio-technological systems influenced by both these so-called 'hard' and 'soft' factors. 'Hard' factors include technology, work processes, accounting systems and formal structure, while 'soft' factors entail aspects such as social dynamics and organisational culture (i.e. the beliefs, values and attitudes applicable to an organisation) as well as leadership capabilities. Lenka and Suar (2008:60) argue that a 'soft' management approach is more applicable to service organisations (i.e. public service). This comprises the 'soft' elements of leadership, human resources, customer focus, management commitment, empowerment, communication and culture (Robbins 2001:510; Sylvie \& Witherspoon 2002:25). A literature survey revealed the 'soft' core determinants shown in Table 1.

Various situational factors or 'hard' determinants have a further impact on organisations' performance and the level of integration or alignment and cooperation. Robbins (1990:457), Johnson and Schiller (1991:56) and Jones and George (2003:92) highlight the following determinants in this regard:

- Organisational structure and design.

- Policies, rules and regulations.

- Strategies.

- Systems. 
TABLE 1: 'Soft' organisational determinants.

\begin{tabular}{ll}
\hline 'Soft' determinants & Scholar(s)/contributor(s) \\
\hline Visionary and inspiring leadership & $\begin{array}{l}\text { Morgan (1989:163-165), Cronje et al. } \\
(1997: 26-27,38), \text { Schroeder, Linderman and } \\
\text { Zhang (2005:28) }\end{array}$ \\
Management styles and roles & Lauterer (2006:310), Milne et al. (2006), Milne \\
& and Taylor (2006), Groves (2009:16) \\
& Mintzberg (1989:273), Senge (1994:239), \\
Teamwork & Roche (1996:3), Sharma and Gadenne \\
& (2001:433), Robbins and Coulter (2005:383) \\
& Sashkin and Morris (1984:117-118), \\
Communication & Mintzberg (1989:208-209), Evans (1990:27); \\
& Sylvie and Witherspoon (2002:16) \\
Employee skills, productivity, & Flynn, Schroeder and Sakakibara (1994:346), \\
motivation, commitment and & Sohn et al. (1999:204), Schroeder et al. \\
empowerment & (2005:472), Robbins and Coulter (2005:245), \\
Zhang (2010:37) \\
Complexity, stability and change & $\begin{array}{l}\text { Robbins and Coulter (2005:256), Westcott } \\
\text { (2006:114), Groves (2009:15) }\end{array}$ \\
Culture & Kotze (2001:13), Mosia (2003:13), O’Donnell \\
& and Boyle (2008:4), Zhang (2010:46) \\
\hline
\end{tabular}

- Processes, methods and procedures.

- Resources (quantity and utilisation).

- Technology.

- Infrastructure and assets.

- Instruments, tools and applications.

- Organisational size.

This concludes a brief orientation of the so-called 'soft' and 'hard' organisational determinants that may impact organisational performance in general and influence the successful alignment of strategies with projects in particular. The following is an overview of management as theory.

\section{Theory and principles of management}

Mary Parker Follet presents the classical definition of management as the art of getting things done through people'. This calls attention to the fact that managers achieve organisational goals by arranging for others to perform whatever tasks may be necessary (Stoner 1982:8). It involves a process of planning, organising, leading and controlling the functions of organisations. In this sense management can be regarded as a process because all managers concerned engage in certain interrelated activities. This includes the optimal utilisation of resources for an organisation's effectiveness, efficiency and productivity, and encouraging the cooperation of employees (Bolden et al. 2003:45).

Management is an extremely broad study field and involves a wide variety of applicable subdomains or branches. These include the management of human resources, change, finances, strategic issues and projects. Managers have to be particularly skilled to manage such specialised functional domains in an organisation (cf. Ahmad \& ud Din 2014:34).

According to Harrison and St John (1998:171) as well as Wheelen and Hunger (1992:172-174), vertical organisational arrangements generally constitute three managerial levels:

- corporate or strategic level - senior or top management responsible for strategic planning and portfolios;
TABLE 2: Managerial determinants.

\begin{tabular}{|c|c|}
\hline Managerial determinants & Scholar(s)/contributor(s) \\
\hline Style & $\begin{array}{l}\text { Lauterer (2006:310), Milne et al. (2006), Milne } \\
\text { and Taylor (2006) }\end{array}$ \\
\hline Functions & Groves (2009:16), Zhang (2010:46) \\
\hline Applications & Stoner (1982:8), Zhang (2010:37) \\
\hline Skills and competencies & $\begin{array}{l}\text { Flynn, Schroeder and Sakakibara (1994:346), Sohn } \\
\text { et al. (1999:204), Schroeder et al. (2005:472) }\end{array}$ \\
\hline $\begin{array}{l}\text { Roles, accountability and } \\
\text { responsibilities }\end{array}$ & $\begin{array}{l}\text { Milne et al. (2006), Milne and Taylor (2006), } \\
\text { Groves (2009:16) }\end{array}$ \\
\hline Authority, power and influence & $\begin{array}{l}\text { Morgan (1989:163-165), Cronje et al. (1997:26, } \\
27,38) \text {, Schroeder et al. (2005:28) }\end{array}$ \\
\hline Span of control & Robbins and Coulter (2005:383) \\
\hline Culture and diversity & $\begin{array}{l}\text { Kotze (2001:13), Mosia (2003:13), O'Donnell and } \\
\text { Boyle (2008:4) }\end{array}$ \\
\hline Creativity & $\begin{array}{l}\text { Kaplan and Norton (2000:1), Robbins and Coulter } \\
(2005: 245)\end{array}$ \\
\hline Stability and change & $\begin{array}{l}\text { Robbins and Coulter (2005:256), Westcott } \\
(2006: 114) \text {, Groves }(2009: 15)\end{array}$ \\
\hline $\begin{array}{l}\text { Productivity, motivation and } \\
\text { performance }\end{array}$ & $\begin{array}{l}\text { Mintzberg (1989:273), Senge (1994:239), Roche } \\
\text { (1996:3), Sharma and Gadenne (2001:433) }\end{array}$ \\
\hline Conflict and level of cohesion & $\begin{array}{l}\text { Sashkin and Morris (1984:117-118), Mintzberg } \\
\text { (1989:208-209), Evans (1990:27), Sylvie and } \\
\text { Witherspoon (2002:16) }\end{array}$ \\
\hline
\end{tabular}

- tactical level - middle management, typically responsible for organisational programmes;

- functional or operational level - first-line or supervisory management, typically responsible for project execution.

Kotze (2001:56) and Van der Waldt (2001:230) argue that effective cooperation and coordination should facilitate this vertical structuring in order to execute strategies successfully.

A literature survey reveals that the effectiveness of management (i.e. successfully coordinating functional processes to align strategies with projects) is influenced by a multitude of determinants. Table 2 briefly identifies these determinants.

The determinants shown in Table 2 are a brief exposition of the core managerial determinants that may influence the successful translation of organisational strategies into service delivery projects. Subsequently, the various principles of strategic management will be examined closer.

\section{Principles of strategic management}

Mintzberg (1994:10-13) regards a 'strategy' as plan, ploy, pattern, position or perspective to give an organisation a competitive advantage over its competitors to achieve its main objectives. Kaplan and Norton (2000:1) add that a strategy is a unique and sustainable instrument through which organisations create value. Strategy is a fluid process according to which managers learn from the environment and thereby develop a plan responsive to the needs of its customers (Lewis 2004:2). Mintzberg (1994:3) further points out that organisational policies, resources and actions should be aligned with its strategies to enhance its performance and outcomes.

Strategic management, according to Pearce and Robinson (1999:3), Sempe (1999:4), as well as Rossouw, Le Roux and 
Groenewald (2003:2), is the process through which an organisation's decisions and actions are derived from environmental scanning with a view to formulate, implement and evaluate its strategies. Thomson and Strickland (1998:24), Fogg (1999:4), Van der Spuy (2008:13) and Kinicki and Williams (2008:178) concur that the benefits of strategic management could be summed up as to provide better direction, momentum and guidance to the entire organisation on the crucial point of what it is trying to do and achieve'.

According to Byars (1992:5) and Sempe (1999:89), strategic management constitutes generic processes that include planning, implementation and evaluation and control of strategies. In the case of the South African Public Service, the South African Treasury Regulations (2000, Part 3, Chapter 5) outline comprehensive steps that public institutions should take to design a strategic plan. These steps are commitment analysis, stakeholder analysis, vision formulation, mission statement, functional analysis, environmental/situational analysis, strategies formulation, action plans, compiling the strategic plan, consultation and agreement, implementation and revision. Its premise is that the performance of public institutions will be enhanced by following these steps.

Cilliers (2000:24) and David (2001:14), as well as Rossouw et al. (2003:1-4), point to the fact that strategic management should be an inclusive process in which senior management, as the custodians of strategic direction, should engage lowerlevel managers constructively in order to align strategies, programmes and projects. This participative engagement of the various management levels generally facilitates commitment, a sense of ownership and joint responsibility for the effective operationalisation of strategies (Kotze 2001: 3-4). By cooperation and coordination between the different levels of management an operational framework should be developed to implement the strategies. This framework should consider the allocation of resources, delegation of authority to lower managerial levels (i.e. project managers). It should also focus on establishing proper monitoring, control and evaluation mechanisms to oversee projects as vehicles to implement strategies (Pearce \& Robinson 1999:7). In addition, Kotze (2001:13) and Mosia (2003:13) point out that an organisation's culture should be adjusted to help apply this operational framework. These scholars point to the need for a culture-strategy 'fit' in the organisation.

A central point is that various authors conceptualise strategic management as an instrument of organisational convergence, i.e. alignment between the various functional activities (cf. Kaplan \& Norton 2000:1; Lewis 2004:2; Mintzberg 1994:10-13). Managers have the responsibility to ensure that the different functional processes are aligned from strategic to operational levels (i.e. projects) in order to obtain a coherent sense of direction. Alignment directs the employees in the organisation to work together and achieve similar objectives. The level of synergy and alignment between the goal and objectives of the organisation, teams and the individuals ultimately determines the success or failure of this organisation.
Byars (1992:5-7) and Wheelen and Hunger (1992:17) suggest that once the strategy has been established, attention should shift to the so-called ' $7 \mathrm{~s}$ ' model of Mckenzie for effective implementation. These ' $7 \mathrm{~s}$ ' entail: shared values, skills, style, staff, strategy, structure and systems. According to Dutta and Manzoni (199:307) the mentioned seven domains, if not appropriately improved or developed, will have far-reaching implications for an organisation's strategy. The successful alignment between strategies (i.e. portfolios, programmes) and projects depends on a wide variety of determinants. Table 3 presents a number of the most prominent determinants in this regard.

Organisational strategy is usually a long-term endeavour and can be difficult to implement in the shorter term. Using a project management approach can help address this paradox. A project-based approach allows an organisation to have clear implementable subobjectives aimed at addressing the overall strategic objectives. After focusing on the principles of strategic management, project management will be examined more closely.

\section{Principles of project management}

The Project Management Institute's (PMI 2016) Project Management Body of Knowledge Guide $\left(\mathrm{PMBOK}^{\circledR}\right)$ defines a project as 'a temporary endeavour undertaken to create a unique product, service or result'. A project has a defined beginning and end in time, and, therefore, defined scope and resources. Projects are unique because they are not part of routine functional operations in an organisation, but rather designed specifically to accomplish a singular goal. A project can also be defined by focusing on its managerial dimensions. These dimensions mainly describe the optimal usage of resources to ensure that the project is completed in time, within budget parameters and according to quality metrics (Clements \& Gido 2009:18; Van der Waldt \& Fox 2015:8). In the same vein, Kerzner (1998:9) defines management of projects as 'any series of activities and tasks that have a

TABLE 3: Strategic management determinants.

\begin{tabular}{|c|c|}
\hline Determinants & Contributor(s)/scholar(s) \\
\hline $\begin{array}{l}\text { Organisational leadership } \\
\text { (administrative/managerial and political) }\end{array}$ & $\begin{array}{l}\text { Sempe (1999:60), Hitt, Ireland and } \\
\text { Hoslusson (2003:145), Mosia (2003:8) }\end{array}$ \\
\hline Organisational culture & $\begin{array}{l}\text { Schermerhorn, Hunt and Osborn } \\
(1997: 267)\end{array}$ \\
\hline Organisational structure & $\begin{array}{l}\text { Robbins (1990:5), Sempe (1999:49), } \\
\text { Kotze (2001:6), Pearce and Robinson } \\
\text { (1999:280-281) }\end{array}$ \\
\hline Management competencies and skills & $\begin{array}{l}\text { Pearce and Robinson (1999:342), Hitt, } \\
\text { Ireland and Hoslusson (2003:10), Sempe } \\
\text { (1999:39), David (2001:245), Mosia } \\
(2003: 9)\end{array}$ \\
\hline Organisational resources & $\begin{array}{l}\text { Bateman and Zeithaml (1990:64), } \\
\text { Schermerhorn et al. (1997:267) }\end{array}$ \\
\hline Efficiency and effectiveness & $\begin{array}{l}\text { Bateman and Zeithaml (1990:64), Sempe } \\
(1999: 56)\end{array}$ \\
\hline Effective communication & $\begin{array}{l}\text { David (2001:89), Kinicki and Williams } \\
(2008: 368)\end{array}$ \\
\hline Coordination & $\begin{array}{l}\text { Sempe (1999:51), Basu (2004:98), Kotze } \\
(2001: 7)\end{array}$ \\
\hline Delegation of authority & $\begin{array}{l}\text { Sempe (1999:51), David (2001:23), Basu } \\
(2004: 102)\end{array}$ \\
\hline Resourcing & $\begin{array}{l}\text { Byars (1992:5-7), Pearce and Robinson } \\
(1999: 342)\end{array}$ \\
\hline
\end{tabular}


specific objective to be completed within specifications; have defined start and end dates; have funding limits; consume human and other resources and are multi-functional'. Burke (2010:8) elaborates on this theme by indicating that this includes planning, organising, directing and controlling activities.

Dmytrenko (1996:74) argues that projects are a 'strategic competency' for organisations, which enable them to link project results to business goals (i.e. private sector) and constitutional mandates (i.e. public sector). In the same vein Graham and Englund (2004:12), Clements and Gido (2009:115, 184) and Hauc and Kovac (2000:64) illustrate the significance of aligning project objectives with broader strategic objectives of the organisation. Meredith and Mantel (2000:44) and Van der Waldt (2009:38) emphasise that strategy alignment is the key determinant when selecting projects. Meredith and Mantel (2000:192) accentuate the need to include system integration as part of integration management for the knowledge domain within the PMBOK. They refer to a 'mixed organisation system' (p. 152) whereby a project is integrated with the organisation's existing functional hierarchical structure. Senior managers need to cooperate in developing a unified strategic emphasis for projects. A structured approach is needed to translate an organisation's strategy into a project management strategy (cf. Burke 2010:138; Van der Waldt 2007:18). In this regard Englund and Graham (1999:56) and Graham and Englund (2004:52) suggest that 'selecting project for their strategic emphasis ... is a corner anchor in putting together the pieces of a puzzle that create an environment for successful projects'. According to DyReyes (2008:53) organisations should adopt 'strategic project management' to facilitate the alignment between strategic objectives and individual projects.

Project management emerged as a management field of study in the early 1960s. Since then various systematic frameworks were designed to depict and execute projects (i.e. life cycle methodologies) and facilitate the integration of projects with existing organisational systems, structures and processes (i.e. maturity models). These methodologies and models are useful instruments to guide the alignment of strategies and projects. Maturity models for organisational project management aim to enhance project value through strategic alignment and by outlining the principles of project-based management (cf. Van der Waldt \& Fox 2015:89-96).

Some of the most common and widely used methodologies for project maturity (i.e. project readiness; cf. Anderseen \& Jessen 2003:4570) include the following:

- PMBOK $^{\circledR}$ (Project Management Body of Knowledge outlining 10 generic knowledge domains);

- PRINCE2 (PRojects IN Controlled Environments, Version 2), a process-based method for effective project management throughout the public and private sectors;

- OPM3 (Organisational Project Management Maturity Model) the ' 3 ' indicating portfolio, programme and project levels;
- EPM (Enterprise Project Management) accentuates the alignment between projects, programmes, portfolios and strategies;

- ISO 21500 (2012), an international standard on project management in public, private or community organisations, and for any type of project, irrespective of complexity, size or duration; and

- IAPPM (International Association of Project \& Program Management) that publishes the Certified Project and Program Manager (CPPM) Guide.

Based on a thorough literature survey, the most significant determinants that influence the successful design and execution of projects as strategic instruments are identified in Table 4.

\section{Integrated framework for strategy- project alignment}

Table 5 reflects a combined list of determinants - organisational, managerial, strategic management and project management as listed in Tables 1-5. This comprehensive list is clustered further based on commonalities between the determinants (i.e. table content). This concludes Phase 2 of the investigation

TABLE 4: Project management determinants.

\begin{tabular}{|c|c|}
\hline $\begin{array}{l}\text { Determinants for successful } \\
\text { project execution }\end{array}$ & Contributor(s)/scholar(s) \\
\hline $\begin{array}{l}\text { Stakeholder engagement and } \\
\text { general communication }\end{array}$ & $\begin{array}{l}\text { Maylor (1996:32, 227), Kerzner (1998:410-411), } \\
\text { Van der Waldt and Knipe (1998:21), Meredith and } \\
\text { Mantel (2000:102-103), Clements and Gido } \\
\text { (2009:32), Burke (2010:98-113), Van der Waldt } \\
\text { and Fox (2015:42) }\end{array}$ \\
\hline $\begin{array}{l}\text { Control, tracking, progress } \\
\text { monitoring, quality metrics }\end{array}$ & $\begin{array}{l}\text { Maylor (1996:139), Van der Waldt and Knipe } \\
\text { (1998:190-192), Meredith and Mantel (2000:462, } \\
\text { 491), Clements and Gido (2009:426), Burke } \\
\text { (2010:234), Van der Waldt and Fox (2015:104- } \\
\text { 105) }\end{array}$ \\
\hline Risk management & $\begin{array}{l}\text { Kerzner (1998:262-263), Burke (2010:258-269), } \\
\text { Van der Waldt and Knipe (1998:61), Meredith and } \\
\text { Mantel (2000:64), Clements and Gido } \\
\text { (2009:89-90), Van der Waldt and Fox (2015:132) }\end{array}$ \\
\hline $\begin{array}{l}\text { Governance, authority, role of } \\
\text { steering committee }\end{array}$ & $\begin{array}{l}\text { Kerzner (1998:233), Van der Waldt and Knipe } \\
\text { (1998:137), Meredith and Mantel (2000:235-238, } \\
\text { 426), Aubry, Hobbs and Thuillier (2007:3280), } \\
\text { Clements and Gido (2009:351), Burke (2010:313), } \\
\text { Van der Waldt and Fox (2015:116-123) }\end{array}$ \\
\hline $\begin{array}{l}\text { Resource planning and } \\
\text { allocation }\end{array}$ & $\begin{array}{l}\text { Maylor (1996:45), Van der Waldt and Knipe } \\
\text { (1998:96, 171), Meredith and Mantel (2000:361- } \\
\text { 367), Clements and Gido (2009:361-367), Burke } \\
\text { (2010:200-209) }\end{array}$ \\
\hline $\begin{array}{l}\text { Project manager and team } \\
\text { member skills, knowledge and } \\
\text { competencies }\end{array}$ & $\begin{array}{l}\text { Maylor (1996:125), Kerzner (1998:239), Meredith } \\
\text { and Mantel (2000:230-231), Clements and Gido } \\
(2009: 338), \text { Burke }(2010: 29,50) \text {, Van der Waldt } \\
\text { and Fox (2015:153-154) }\end{array}$ \\
\hline $\begin{array}{l}\text { Organisational leadership } \\
\text { (administrative/managerial } \\
\text { and political) }\end{array}$ & $\begin{array}{l}\text { Van der Waldt and Knipe (1998:186-192), Kerzner } \\
\text { (1998:742), Burke (2010:31), Van der Waldt and } \\
\text { Fox (2015:151-152) }\end{array}$ \\
\hline $\begin{array}{l}\text { Cost, procurement, supply } \\
\text { chain }\end{array}$ & $\begin{array}{l}\text { Maylor (1996:86), Kerzner (1998:551), Meredith } \\
\text { and Mantel (2000:264), Clements and Gido } \\
(2009: 267,270-272) \text {, Burke }(2010: 214,217)\end{array}$ \\
\hline $\begin{array}{l}\text { Legislative, policy, regulations } \\
\text { compliance }\end{array}$ & $\begin{array}{l}\text { Van der Waldt and Knipe (1998:109-118), } \\
\text { Meredith and Mantel (2000:98, 103), Burke } \\
\text { (2010:33), Van der Waldt and Fox (2015:13) }\end{array}$ \\
\hline Use of technology & $\begin{array}{l}\text { Kerzner (1998:678), Meredith \& Mantel } \\
\text { (2000:422-423), Clements \& Gido (2009:380), } \\
\text { Burke (2010:240), Van der Waldt and Fox } \\
(2015: 132)\end{array}$ \\
\hline $\begin{array}{l}\text { Team work, coordination and } \\
\text { cooperation }\end{array}$ & $\begin{array}{l}\text { Maylor (1996:126), Meredith and Mantel } \\
\text { (2000:160-169), Clements and Gido (2009:344), } \\
\text { Burke (2010:316-327) }\end{array}$ \\
\hline $\begin{array}{l}\text { Flexible matrix or project- } \\
\text { based organisational structure }\end{array}$ & $\begin{array}{l}\text { Van der Waldt and Knipe (1998:64), Kerzner } \\
\text { (1998:114-115), Burke (2010:310-312), Van der } \\
\text { Waldt and Fox (2015:89-96) }\end{array}$ \\
\hline
\end{tabular}


(see Figure 1): applying the principles of interdisciplinarity to obtain an integrated perspective.

Based on these determinant clusters, an empirical investigation was undertaken in SASSA as a case study (i.e. Phase 3). This was carried out, firstly, to determine how these determinants currently influence the organisation; secondly, to establish to what extent SASSA's strategies are aligned with its projects and, thirdly, to pinpoint particular challenges in this regard (i.e. Phase 4). These clusters were integrated in the form of questions as part of an interview schedule that was used as the instrument to collect data. The research methodology employed in the present investigation as well as its core findings are outlined in the following section.

\section{Research methodology}

Remenyi (1996:24) maintains that research can be defined as 'a voyage of discovery'. If researchers claim that their research does add valuable information to the existing body of knowledge, they must comply with the 'scientific method'. Welman, Kruger and Mitchell (2005:2) define this scientific method as a process of generating scientific knowledge by objective methods and procedures in a particular field of study.

The author of this article followed a qualitative research design. Struwig and Stead (2001:25) and Maree et al. (2007:51) describe the qualitative approach as research concerned with understanding the social and cultural dimensions of phenomena. The strength of qualitative research is its ability to provide complex textual descriptions of how people experience a given issue. Because the perceptions and opinions of senior managers as participants from SASSA are significant for purposes of the present investigation, the qualitative research design was found particularly suitable.

\section{Case-study instrumentation}

Yin (2012:23) defines the case-study research method as an empirical inquiry that investigates a contemporary phenomenon within its real-life context. A case study typically involves a number of units of analysis that should be representative of the population under investigation. Schurink (2010:437-438) is of the opinion that a case study is an exploration or in-depth analysis of a 'bounded system' linked to time and/or place, or it can entail a multiple or single case over a period of time. The scholar further argues that in qualitative research, case studies emphasise the detailed contextual analysis of a limited number of events or conditions and their relationship. For the purposes of this research the case-study method was, therefore, followed to investigate SASSA's functionality and processes in terms of strategy and project alignment.

\section{Units of analysis and sampling}

A unit of analysis, as defined by Bless and Higson-Smith (2000:72), refers to a person, object or event to be studied and from which data are to be collected and conclusions drawn. SASSA's head office in Pretoria oversees nine regional offices. The unit of analysis are the Gauteng Regional Office

TABLE 5: Combined determinants influencing strategy-project alignment.

\begin{tabular}{|c|c|c|c|c|}
\hline \multicolumn{2}{|c|}{ Organisational } & Management & Strategic management & Project management \\
\hline - & Leadership & Authority, power and influence & Leadership & Leadership (managerial and political) \\
\hline$\bullet$ & $\begin{array}{l}\text { Organisational structure } \\
\text { and design } \\
\text { Systems } \\
\text { Organisational size }\end{array}$ & Span of control & Structure & $\begin{array}{l}\text { Flexible matrix or project-based } \\
\text { organisational structure }\end{array}$ \\
\hline - & $\begin{array}{l}\text { Management styles } \\
\text { and roles }\end{array}$ & $\begin{array}{ll}\text { - } & \text { Style } \\
\text { - } \quad \text { Roles, accountability and } \\
\text { responsibilities }\end{array}$ & - Delegation of authority & $\begin{array}{l}\text { - Governance, authority, role of steering } \\
\text { committee }\end{array}$ \\
\hline • & Teamwork & $\begin{array}{l}\text { - Productivity, motivation and } \\
\text { performance }\end{array}$ & - $\quad$ Efficiency and effectiveness & $\begin{array}{l}\text { Team work, coordination and } \\
\text { cooperation }\end{array}$ \\
\hline • & $\begin{array}{l}\text { Employee skills, productivity, } \\
\text { motivation, commitment, } \\
\text { empowerment }\end{array}$ & - $\quad$ Skills and competencies & - $\quad$ Competencies and skills & $\begin{array}{l}\text { - Project manager and team member } \\
\text { skills, knowledge and competencies }\end{array}$ \\
\hline & & - $\quad$ Creativity & & $\begin{array}{l}\text { - Control, tracking, progress monitoring, } \\
\text { quality metrics }\end{array}$ \\
\hline - & Communication & $\begin{array}{l}\text { - Stability and change } \\
\text { - } \quad \text { Conflict and level of cohesion }\end{array}$ & $\begin{array}{l}\text { - Communication } \\
\text { - Coordination }\end{array}$ & $\begin{array}{l}\text { - Stakeholder engagement and } \\
\text { communication }\end{array}$ \\
\hline $\begin{array}{l}\bullet \\
\bullet \\
\bullet\end{array}$ & $\begin{array}{l}\text { Technology } \\
\text { Resources } \\
\text { Infrastructure and assets } \\
\text { Instruments, tools and applications }\end{array}$ & Applications & Resourcing & $\begin{array}{ll}\text { - } & \text { Technology } \\
\text { - } & \text { Resources } \\
\text { - } & \text { Cost, procurement, supply chain }\end{array}$ \\
\hline$\bullet$ & $\begin{array}{l}\text { Policies, rules and } \\
\text { regulations } \\
\text { Strategies } \\
\text { Processes, methods and procedures }\end{array}$ & Functions & & $\begin{array}{l}\text { - } \quad \text { Legislative, policy, regulation } \\
\text { compliance } \\
\text { - } \quad \text { Risk management }\end{array}$ \\
\hline$\bullet$ & $\begin{array}{l}\text { Culture } \\
\text { Complexity, stability and change }\end{array}$ & Culture and diversity & Culture & Team dynamics \\
\hline
\end{tabular}


comprising five districts and several service points (shown in Table 6). From these districts, five District Managers and 18 Local Offices Managers were purposively sampled as participants in the research due to their direct involvement in the translation of organisational strategies into operational projects.

\section{Data collection: Interviews}

The instrument for data collection in the present investigation was semi-structured interviews. An interview schedule was designed based on the theory, principles and key determinants of organisation, management, strategic management and project management as reflected in Tables 1-4. This instrument was pre-tested (piloted) with three participants to confirm that the questions were clear and that the participants fully understood its nature. The schedule consisted of closed as well as open-ended questions. The latter allowed the author to probe the responses further and to clarify answers. Questions were constructed to assess the extent to which strategies and projects were aligned and to identify the particular challenges that senior management experienced in this regard.

In adherence to the guidelines for ethical research, the author obtained permission from the Office of the CEO of SASSA to conduct the interviews. In total, 28 of the selected $(n=38)$ participants participated, a response rate thus of $73.6 \%$. This response rate was fully adequate for purposes of obtaining valid and reliable data for the nature of this investigation.

\section{Analysis of findings}

The data are presented in two sections, namely Section A, which provides the biographical details of participants, and Section B, capturing the responses to the questions.

\section{Section A: Biographical information}

The biographical data of the participants selected from SASSA's Gauteng regional managers, as well as for district and local office managers, are reflected in Table 7. This indicates the managerial level of participants in the SASSA regional and local offices. Biographical information of participants was needed to enable an analysis of potential divergent responses by participants based on their experience (i.e. years of service in SASSA), seniority and involvement in strategy-project alignment.

\begin{tabular}{lc} 
TABLE 6: SASSA Gauteng Regional Office. & \\
\hline District name & Service points \\
\hline Johannesburg & 6 \\
West Rand & 9 \\
Sedibeng & 5 \\
Ekhuruleni & 6 \\
North Rand & 12 \\
\hline Total & $\mathbf{3 8}$
\end{tabular}

Source: South African Social Security Agency (SASSA), 2016, Head Office and Regional Offices, viewed 10 February 2016, from http://www.sassa.gov.za/index.php/contact-us/ head-office-and-regional-contacts
TABLE 7: Participants' management levels.

\begin{tabular}{lccc}
\hline Management level & $\begin{array}{c}\text { Regional } \\
\text { office }\end{array}$ & $\begin{array}{c}\text { District and } \\
\text { local offices }\end{array}$ & Total \\
\hline Director/Senior Manager (level 13) & 2 & 4 & $\mathbf{6}$ \\
Manager/Deputy Director (level 12) & 4 & - & 4 \\
$\begin{array}{l}\text { Local Office Managers/Deputy } \\
\text { Managers (level 12) }\end{array}$ & - & 18 & $\mathbf{1 8}$ \\
\hline Total & & & $\mathbf{2 8}$ \\
\hline
\end{tabular}

\section{Section B: SASSA as case}

SASSA is a national agency created in April 2005, with the aim to administer the application, approval and payment of social grants in South Africa. SASSA is a Section 3A public entity (SASSA, Strategic Plan 2013/14-2015/16) and was established in terms of the Social Assistance Act 13 of 2004 and the South African Social Security Agency Act 9 of 2004.

The presentation of the findings focuses on the current status of SASSA based on the responses of participants. The data are categorised below into organisational, management, strategy and project dimensions.

\section{Status of organisation}

SASSA operates through nine regional offices, one each in the nine provinces, and the Head Office is situated in Pretoria, Gauteng. The regional, district, local and satellite offices are thus located throughout the country. The agency is structured into six portfolios to deliver on its strategic objectives. These portfolios are: Grant Administration, Strategy and Business Development, Information and Communication Technology, Internal Audit and Risk Management and Corporate Services (SASSA Annual Performance Plan 2015/16:41-44).

Two Directors (2/6), 2 Senior Managers (2/4) and 10 Local Office Managers (10/18) confirmed that SASSA currently operates with no uniform organisational structure. Furthermore, based on the comments by the participants, it seems that new positions are created without adequate work study or requirements to develop the organisation. Certain provinces, such as the Western Cape, function without district offices, which makes national coordination problematic.

\section{Status of management}

Participants confirmed that a total of $188(60 \%)$ of the 331 local offices are operating on a standardised business model. Business processes have been mapped and frontline employees are trained regularly on the effective functioning of these processes. The aim is to eliminate duplication in functions while at the same time delivering quality, by adding a function for quality assurance to the value chain for grants.

The majority of the participants $(64.2 \%)$ concurred that the bureaucratic and hierarchical nature of management planning and decision-making is hampering coordination and cooperation in the agency. Authority, resources and planning are centralised at higher levels of management, while implementation, responsibility and accountability are 
decentralised to lower levels. For instance, although the need for resources may be determined at district or local offices, only the regional or Head Office may approve the allocation and distribution of resources. Managers are expected to deliver on their performance contracts, irrespective of whether or not they have the required resources at their disposal.

The lack of clarification on roles and responsibilities among managers in the regional, district office and local offices was further singled out by participants $(57.1 \%)$ as a factor causing strenuous relationships between managers at all levels. The alignment of functions and delegation of powers from the regional offices to the local offices varies from one province to another. Some regional offices decentralise functions and resources to the lower level and some centralise certain functions to the regional office.

Furthermore, an audit finding in the past years pointed out the lack of alignment and integration among systems from various managerial levels and processes of SASSA. The Social Grants Payment and Administration System (SCOPEN), for example, is not aligned fully with the accounting systems (i.e. Oracle and the Basic Accounting System [BAS]). Communication and information technology are found to be designed inadequately to comply with the requirements of the Grants Administration System (i.e. Novel software applications and MTN short messages system).

\section{Status of strategy}

All the participants indicated that SASSA has developed vision and mission statements, as well as strategies to fulfil its statutory and constitutional mandates. The vision of the agency is to be a leader in delivery of social security services and its mission is to administer quality customer-centric social services. The strategic objective of SASSA is to 'create a high performing institution to improve administration of social security in a manner that meets stakeholder expectation' (cf. SASSA Strategic Plan 2013/14-2015/16). Key strategic portfolios are Beneficiary Maintenance and Customer Care. Key strategic programmes support these portfolios, namely:

- service-delivery improvement programme;

- automation of business processes; and

- mass beneficiary enrolment.

\section{Status of projects}

Participants in the research generally concurred that projects are identified somewhat haphazardly according to business units (i.e. district office), mainly when crisis situations emerge. SASSA's success is determined largely by its ability to execute projects that are aligned to the vision, mission and strategic objectives, as provided for in the Annual Performance Plan (APP). Its strategic plan sets out six organisational branches to operate the agency's programmes within the scope of available resources. These branches' function is to ensure that the relevant programmes are aligned to the objective statements of the organisation and are converted into various projects.
However, participants indicated that, during its strategic planning phase, the agency does not adequately involve functional managers and operational staff who execute projects. As one participant noted, 'This creates a strategic challenge for SASSA; not to align the projects with what senior management wishes to achieve'. Furthermore, participants reflected that functional managers have full control over their business units for personnel and budgets. Each unit designs and executes projects without effective coordination between units and offices. In addition, support units (i.e. administration and human resources) are not involved adequately in the initiation phases of projects, and this generally leads to problems with projects' feasibility.

\section{Strategy-project alignment challenges}

In their responses, participants identified the strategy-project alignment challenges as listed below in the order of number of responses received. The number of (related) responses appears as a percentage of the total $(n=28)$ in brackets after each challenge. Because the purpose of this phase was merely to identify challenges, there was no need to differentiate between the sampled cohorts (i.e. managers of regional, district and local offices):

- Centralised planning: The national Department of Social Development (DSD) as the 'mother body' unilaterally makes decisions to set up certain projects without consulting SASSA as its 'delivery wing'. This often leads to the duplication of projects. For example, SASSA executes a number of short-term ad hoc projects spearheaded by the DSD, which are not aligned fully with SASSA's strategic objectives or with existing strategic programmes. These projects are based more on 'political motives' and have serious implications for the agency's available resources. Furthermore, conceptualisation of projects usually occurs at a centralised level, most often at Head Office. However, the monitoring and accountability for implementing these projects is decentralised to managers at district and local offices. This often leads to 'fiscal dumping' and project 'mushrooming' in these offices due to savings realised in departmental budget votes. Failure to comply with expectations from higher authority in the organisation is viewed as poor performance or under-performance. This results in low morale, lack of commitment and absenteeism of staff in the district and local offices (67.8\% of participants).

- Project governance: SASSA does not have an official coordinating mechanism or governance structure in place, for example, a project management office (PMO) to facilitate the strategic alignment of projects. Such a structure could ensure the optimal usage of scarce departmental resources and help provide organisational, technical and interpersonal interfaces. The Annual Financial Performance Report (2012-2013) of SASSA indicated that the absence of a programme and PMO needs to be addressed because this condition generally leads to fruitless and wasteful expenditure. The agency 
has since then employed a project manager for this purpose, but no support staff are in place. SASSA also does not utilise steering committees fully for its larger projects. In the absence of such committees, it is extremely difficult for the agency to ensure that the project scope aligns with objectives for programmes and strategies (57.1\% of participants).

- Technological support: Participants generally agreed that SASSA does not have an adequate ICT support system to execute the planned strategies and projects effectively. The main reason is the limited support staff. As one participant from the ICT Unit explained:

\begin{abstract}
'In deploying the ICT equipment to the local offices, the same person from the local office is expected to assist all ICT unit managers as and when the need arises and be committed to the respective units' projects and also to their own work they have been appointed to do ... within the entire Gauteng region there are only two permanent ICT technician posts. Gauteng has 1105 staff members. These two technicians are expected to roll out ICT equipment in 44 Offices! They should also monitor performance of IT equipment. Based on the number of crossfunctional projects that are being implemented, the day-to-day ICT functional priorities are often neglected.'
\end{abstract}

Another participant explained the lack of adequate service follow-ups:

'The monitoring of tools that were provided as solutions is not done and with the ICT Unit having limited human resources, analysing if the end product meets the business objectives, identified at the beginning of the project, does not happen. The lack of such monitoring activities limits the Unit's opportunity to improve on ICT offering and measuring if the customer is satisfied with what we provided as a solution.'

- Organisational arrangements and authority: From participants' input, it seems that the working environment is not fully conducive to project-based operations. As one participant stated, 'The organisation is not flexible to accommodate ad hoc projects and does not easily allow for change'. Participants also mentioned that officials generally find themselves embroiled in 'authority conflicts' between functional and project managers over project's priorities, administrative tasks, allocation of staff and performance standards. There is also 'fragmented reporting' with multiple reporting lines and templates. Furthermore, most employees are 'rank conscious', which causes problems for adequate delegation of authority to project managers of lower ranks (42.8\% of participants).

- Project feasibility: It is evident that currently projects are executed without conducting proper feasibility studies. One participant explained: 'Projects are not properly planned, and not strategically prioritised ... this causes that they are not properly funded or resourced'. Furthermore, important projects such as Grant Re-registrations, Standardisation of Local Offices and Eradication of Fraud and Corruption were not successful. This was mainly due to unclear or ambiguous objectives, insufficient planning, poor communication, lack of resources and unrealistic timescales. As a participant explains: 'The implementation of these projects was received with resistance. Staff members felt that projects are just dumped on them one project after the other' (35.7\% of participants).

- Quality control: A point of significant concern within the entire organisation was pointed out as implementation of effective standards and controls for the design, development, implementation, maintenance, use, acquisition and management of project deliverables. The absence of standardised project standards and quality metrics does not necessarily align with crucial aspects such as core business strategies, legislated workflow standards and operational procedures (21.4\% of participants).

- Budgeting: Participants explained that the Agency receives two types of budget transfers from the DSD, for grant payments and to cover the administrative costs of the branches. The budget is available and approved, but is informed by the previous year's expenses. The fact that the budget is not informed by projects' work breakdown structures (WBSs) usually leads to over-or underspending. In this regard one participant also alluded to the fact that the budgeting process '... opens the organisation to fraud and corruption because employees may collude with the providers of tenders'. There is also no standardised methodology for project budgeting in place to calculate in detail the direct and indirect costs of project tasks and other required resources.

Furthermore, a number of interviewees stated that the meeting schedule of the Regional Acquisition Committee (RAC) does not necessarily align with the deadlines of the fiscal year. As one participant explained:

'When the RAC finally gives approval, there are only about four few weeks left for the supplier to deliver equipment. Payment of suppliers must be done within 30 days as stipulated by the Public Finance Management Act 1 of 1999 . Then there is also the challenge that the Oracle system used to pay suppliers also closes by the first week of March. Due to the uncoordinated manner in which projects are implemented you will find a situation where a laptop is deployed without a $3 \mathrm{G}$ card, yet the project aim is to have a mobile service point.'

\section{Recommendations to address strategy-project alignment challenges}

Based on the literature review and the input obtained from participants, this section briefly posits recommendations that SASSA, and similar public sector institutions, should consider in improving the alignment of their strategies and projects. The recommendations are arranged according to the challenges highlighted in the previous section:

- Project planning: Centralised strategic planning is necessary to provide visionary leadership and give direction to the entire organisation nationwide. However, it is imperative to follow an all-inclusive and participatory approach to foster commitment and responsibility among the relevant role-players for the institution's goals. When developing departmental strategies, input from all the 
relevant key stakeholders, including lower-level staff and prospective project managers, should be prioritised to encourage joint ownership, buy-in and support.

- Project governance: To obtain an integrated view of the projects undertaken by different branches, regions and districts in the organisation, it is recommended that a PMO be established. Such a PMO can fulfil the following functions: encourage a project management culture, ensure that strategies and projects are aligned, facilitate the allocation of resources, provide a consolidated perspective of progress on the projects and ensure good governance of the programmes and projects.

- Technological support: It is recommended strongly that SASSA extends its ICT capacity by deploying more support staff to the district and local offices (i.e. project implementation sites). The design of a comprehensive Project Management Information System (PMIS) could help provide a perspective of integrated enterprises to track and manage projects. It could also ensure that the various projects of the district and local offices remain aligned to strategic objectives.

- Organisational arrangements and authority: Public institutions such as SASSA generally operate in multiproject environments. Therefore, they should increasingly use project methodology to operationalise strategic programmes and implement initiatives for service delivery. Project management should be the focal point for senior managers in the formulation of strategies. The different organisational units should work in an integrated and coordinated manner and provide the necessary support to each other. The organisations should furthermore become more flexible, agile and project-based. SASSA could start the process by implementing the principles of a matrix organisation and, as it matures, gradually move towards a projectbased structure. It is further recommended that adequate authority should be delegated to project managers, enabling them to manage projects properly. Head Office should also devolve and delegate decision-making powers to district and local offices.

- Project feasibility: Scientific feasibility studies should precede the approval of all projects. Such studies should include environmental impact assessments, risk analyses, organisational capacity and capability assessments, as well as cost-benefit analyses. Data from feasibility studies should also provide both qualitative and quantitative metrics for the prioritisation of projects.

- Quality control: It is necessary to further adequate performance monitoring, evaluation, assessment and oversight of all projects. Therefore, it is recommended that SASSA design appropriate quality standards and metrics for the typical projects executed in their strategic portfolios. Such a quality framework should map the contribution of each project to the strategic business decisions and empower managers to determine whether projects are meeting or exceeding the set targets and standards.
- Budgeting: Budgets should be informed adequately by detailed project and district planning. In addition, local offices should be afforded sufficient powers to form their own bid committees to help fast-track the procurement of resources.

- General recommendations: Other recommendations, to facilitate the alignment of strategy projects, include the following:

- Apply internationally accepted strategies and best practice for projects and benchmark these practices with similar organisations.

- Introduce a uniform project management methodology such as PMBOK or PRINCE2 across the organisation and gain the commitment and active support of senior managers to help establish conducive structures, systems and methodology to support programmes and projects.

- Improve general strategic management and project management skills, which include a mind-set change by senior officials to follow a project-based approach in improving service delivery.

- Ensure optimal utilisation of scarce departmental resources by facilitating alignment through formal and informal reporting relationships among the following entities: different organisational units or directorates (organisational interfaces); different technical disciplines and functional areas (technical interfaces); and different individuals working on the programme and projects (interpersonal interfaces).

- Managing projects by strategic usage of these resources: A steering committee could, for example, ensure that a particular project obtains relevant resources from various functional directorates (i.e. organisational interfaces); secure assistance from ICT (i.e. technical interfaces); and frequently bring the relevant roleplayers (i.e. heads of the directorates) to the table. This would help establish work practices and foster sound working relationships (i.e. interpersonal interfaces) for improved cooperation and coordination.

\section{Conclusion}

The principles of interdisciplinarity, systems thinking and organisational integration accentuate the need to view organisations as integrated systems. Organisational effectiveness depends not only on the formulation of strategies to direct the processes and operations towards a desired future (i.e. vision), but also on the successful conversion of strategies into operational action. Increasingly, public institutions such as SASSA operate in multi-project environments in which projects are used as instruments to implement strategies. However, a major reason for project failure is that most organisations do not ensure that all their projects are aligned with core strategies.

The purpose of this article was to combine the principles of organisation, management, strategic management and project management and thereby identify core determinants that could determine how and to what extent SASSA, as a 
case study, manages its alignment of strategy projects. The identified determinants were utilised to uncover particular challenges for the organisation to align their strategies and projects successfully. Based on the responses of participants it is evident that SASSA has adequate strategic processes, resources, systems, structures and processes in place to comply with its constitutional mandate. However, the alignment between strategies and projects, especially between Head Office, regional, district and local offices, requires serious attention. A detailed framework for strategyproject alignment could go a long way in ensuring that public institutions, such as SASSA, function fully according to their mandates and, ultimately, improve service delivery across their spheres of operation countrywide.

\section{Acknowledgements Competing interests}

The author declares that he has no financial or personal relationship(s) which may have inappropriately influenced him in writing this article.

\section{References}

Abel, C.F., 1999, Schools of organisation theory, viewed 21 January 2016, from http:// www2.sfasu.edu/polisci/Abel/142/schoolsoforganizationtheory.html

Ahmad, I. \& Ud Din, S., 2014, Evaluating training and development, Gomal University Press, Gomal.

Anderseen, E.S. \& Jessen, S.A., 2003, 'Project maturity in organisations', Cost Engineering 40(4), 457-461. http://dx.doi.org/10.1016/s0263-7863(02)00088-1

Aubry, M., Hobbs, B. \& Thuillier, D., 2007, 'A new framework for understanding organisational project management through the PMO', International Journal of Project Management 25(1), 328-336. http://dx.doi.org/10.1016/j.ijproman.2007.01.004

Baker, K.A. \& Branch, K.M., 2002, Concepts underlying organisational effectiveness: Trends in the organisation and management science literature, viewed 04 February 2016, from http://www.au.af.mil/au/awc/awcgate/doe/benchmark/ index.htm

Basu, R., 2004, Implementing quality, Thomson, London.

Bateman, T.S. \& Zeithaml, C.P., 1990, Management: Function and strategy, Irwin, Homewood, IL.

Bless, C. \& Higson-Smith, C., 2000, Fundamentals of social research methods: An African perspective, 3rd edn., Juta, Cape Town.

Bolden, R., Gosling, J., Marturano, A. \& Dennison, P., 2003, A review of leadership theory and competency frameworks, Centre for Leadership Studies, University of Exeter, Exeter.

Burke, R., 2010, Fundamentals of project management: Tools and techniques, Everbest, Hong Kong.

Byars, L.L., 1992, Concepts of strategic management: Formulation and implementation, 3rd edn., Harper Collins, New York.

Churchman, C.W., 1968, The systems approach, Dell, New York.

Cilliers, C., 2000, Fundamental criminal justice, UNISA, Pretoria.

Clements, J.P. \& Gido, J., 2009, Effective project management, 4th edn., SouthWestern Cengage Learning, Toronto.

Cronje, J., Hugo, W.M.J., Neuland, E.W. \& Reenen, M.J., 1997, Introduction to business management, 3rd edn., Southern Book, Cape Town.

David, F.R., 2001, Strategic management concepts and cases, 8th edn., Prentice Hall, New York.

Dawson, S., 1993, Analysing organisations, Macmillan, London.

Dmytrenko, A.L., 1996, 'Successful project management', Records Management Quarterly 30(1), 74-75.

DyReyes, J., 2008, Strategic project management: Aligning strategic business objectives with project management strategy', viewed 16 February 2016, from https://scholarsbank.uoregon.edu/xmlui/bitstream/handle/1794/7678/2008dyreyes.pdf?sequence $=1$

Englund, R.L. \& Graham, R.J., 1999, 'From experience: Linking projects to strategy Strategic boundaries between order and chaos in organisations', Journal of Product Innovation Management 16(1), 52-64. http://dx.doi.org/10.1016/S07376782(98)00046-0

Evans, P., 1990, Human resource management in international firms, Macmillan, London. Fauconnier, G., 1987, Aspects of the theory of communication, 2nd edn., Academica, Pretoria.
Flynn, B.B., Schroeder, R.G. \& Sakakibara, S., 1994, 'A framework for quality management research and an associated measurement instrument', Journal of Operations Management 11(4), 339-366. http://dx doi.org/10.1016/S0272Operations Manage
$6963(97) 90004-8$

Fogg, C.D., 1999, Implementing your strategic plan, AMACOM, New York.

Gitlow, H.S., Oppenheim, A.J., Oppenheim, R. \& Levine, D.M., 2005, Quality management, 3rd edn., McGraw-Hill, Boston, MA.

Glans, T.B., Grad, G., Holstein, D., Meyers, W.E. \& Schmidt, R.N., 1968, Management systems, Holt, Rinehart \& Winston, New York.

Graham, R.J. \& Englund, R.L., 2004, Creating an environment for successful projects, 2nd edn., Jossey-Bass, San Francisco, CA.

Groves, J., 2009, 'Understanding the change to integration: An organizational analysis of a small newspaper', PhD thesis, University of Missouri, Columbia, MO.

Harrison, J.F. \& St. John, C.H., 1998, Strategic management of organisations and stakeholders: Concepts and cases, International Thompson, London.

Hauc, A. \& Kovac, J., 2000, 'Project management in strategy implementation: Experiences in Slovenia' International Journal of Project Management 18(1) 61-67. http://dx.doi.org/10.1016/S0263-7863(98)00071-4

Hitt, M.A., Ireland, R.D. \& Hoslusson, R.E., 2003, Strategic management competitiveness and globalization, 5th edn., Thompson, Cincinnati, $\mathrm{OH}$.

Johnson, S. \& Schiller, F., 1991, The how to manage handbook, Prentice Hall, Upper Saddle River, NJ.

Jones, G.R. \& George, J.M., 2003, Contemporary management, 3rd edn., McGraw-Hill, London.

Kaplan, R.S. \& Norton, D.P., 2000, 'Having trouble with your strategy? Then map it', in Harvard business review, viewed 22 February 2016, from https://hbr.org/2000/09/ having-trouble-with-your-strategy-then-map-it

Kast, F.E. \& Rosenzweig, J.E., 1974, Organization and management: A systems approach, McGraw-Hill, New York.

Kerzner, H., 1998, Project management: A systems approach to planning, scheduling, and controlling, 6th edn., Van Nostrand Reinhold, New York.

Kinicki, A. \& Williams, B.K., 2008, Management: A practical introduction, 3rd edn., McGraw-Hill, New York.

Kleinberg, E., 2008, 'Interdisciplinary studies at a crossroads', Liberal Education 94(1), 6-11.

Kotze, J., 2001, 'Strategic management', Study guide MPTP, North West University, Potchefstroom.

Lauterer, J., 2006, Community journalism: Relentlessly local, University of North Carolina Press, Chapel Hill, NC.

Lenka, U. \& Suar, D., 2008, 'A holistic model of total quality management in services', ICFAI Journal of Management Research 7(3), 56-72.

Lewis, J., 2004, Project planning, scheduling and control: A hands-on guide to bringing projects in on time and on budget, McGraw-Hill, New York.

Luhmann, N., 2013, Introduction to systems theory, Polity, Cambridge.

Maree, K., Creswell, J.W., Ebersohn, L., Eloff, I., Ferreira, R., Ivankova, N.V. et al., 2007, First steps in research, Van Schaik, Pretoria.

Maylor, H., 1996, Project management, Pitman, London.

McNamara, C., 2008, Thinking about organisations as systems, viewed 02 February 2016, from http://managementhelp.org

Meredith, J.R. \& Mantel, S.J., 2000, Project management: A managerial approach, 4th edn., John Wiley, New York.

Milne, C., Rau, A., Du Toit, P. \& Mdlongwa, F., 2006, Key editorial and business strategies: A case study of six independent community newspapers, Mega Digital, Cape Town.

Milne, C. \& Taylor, A., 2006, African media development initiative. South Africa research findings and conclusions, BBC World Service Trust, London.

Mintzberg, H., 1989, Mintzberg on management: Inside our strange world or organisations, Free Press, New York.

Mintzberg, H., 1994, The rise and fall of strategic planning, Free Press, New York.

Mobley, W.H., Wang, L. \& Fang, K., 2005, 'Organisational culture: Measuring and developing it in your organisation', in The Link, Summer. Knowledge@CEIBS, viewed 21 May 2015, from http://www.ceibs.edu/link/latest/images/20050701/ 1394.pdf

Morgan, G., 1989, Creative organisation theory. A resource book, Sage, Newbury Park, CA.

Mosia, M.S., 2003, 'The importance of strategic leadership in strategy implementation in a chemical industry', MA dissertation, North West University, Potchefstroom.

O'Donnell, O. \& Boyle, R., 2008, Understanding and managing organisational culture, CPMR Discussion Paper 40. Institute of Public Administration, viewed 13 July 2015, from http://www.ipa.ie

Pearce, J.A. \& Robinson, R.B., 1999, Strategic management. formulation, implementation, and control: International edition, Irwin McGraw-Hill, Boston, MA.

Project Management Institute (PMI), 2016, The standard for project management, Project Management Institute, Newtown Square, PA, viewed 18 February 2016 from http://www.pmi.org/About-Us/About-Us-What-is-Project-Management.aspx

Remenyi, D., 1996, 'So you want to be an academic researcher in business and management studies. Where do you start and what are the key philosophical issues to think about?', South African Journal of Business Management 27(1/2), 22-33. 
Robbins, S.P., 1990, Organisational behaviour, Prentice-Hall, Upper Saddle River, NJ.

Robbins, S.P. 2001. Organisational behaviour, rev. edn., Prentice-Hall, Upper Saddle River, NJ.

Robbins, S.P. \& Coulter, M., 2005, Management, 8th edn., Prentice Hall, Upper Saddle River, NJ.

Roche, J.F., 1996, 'Total quality journalism: An integrated management approach to the news', MA dissertation, University of South Carolina.

Rossouw, D., Le Roux, S.J. \& Groenewald, D., 2003, Strategic management: An applied South African perspective, New Africa Books, Cape Town.

Roth, C.E., 1992, Environmental literacy: Its roots, evolution and directions in the 1990s, Ohio State University Press, Columbus, OH.

Sashkin, M. \& Morris, W.C., 1984, Organisational behavior. Concepts and experiences, Reston, Reston, VA.

SASSA, 2012, Annual performance plan 2012/2012 - 2014/15, Government Printers, Pretoria.

SASSA, 2013, National strategic plan for the Fiscal Year 2013/14 - 2016/17, Government Printers, Pretoria.

Schermerhorn, J.R., Hunt, J.G. \& Osborn, R.N., 1997, Organisational behaviour, Wiley, New York.

Schroeder, R.G., Linderman, K. \& Zhang, D., 2005, 'Evolution of quality: First fifty issues of production and operations management', Production and Operations Management 14(4), 468-481. http://dx.doi.org/10.1111/j.1937-5956.2005. tb00234.x

Schurink, W., 2010, 'The importance of theorising in a proposal', Journal of Public Administration 45(3), 420-434.

Sempe, K.E.G., 1999, 'Strategy implementation in the Bloemfontein Transitional Loca Council', MA dissertation, North West University, Potchefstroom.

Senge, P.M., 1994, The fifth discipline. The art and practice of the learning organisation, Currency Doubleday, New York.

Sharma, B. \& Gadenne, D., 2001, 'Importance and effectiveness of quality management approaches', The TQM Magazine 13(6), 433-443. http://dx.doi.org/ 10.1108/EUM0000000006180

Shenhar, A.J., Dvir, D., Levy, O. \& Maltz, A.C., 2001, 'Project success: A multidimensional strategic concept', Long Range Planning 34(6), 699-725. http://dx.doi. org/10.1016/S0024-6301(01)00097-8

Sohn, A.B., Wicks, J.L., Lacy, S. \& Sylvie, G., 1999, Media management: A casebook approach, Lawrence Erlbaum, Mahwah, NJ.

South Africa (Republic). Public Finance Management Act 1 of 1999, Government Printers, Pretoria.

South Africa (Republic). National Treasury, 2000, National Treasury Regulations, Government Printers, Pretoria.
South African Social Security Agency (SASSA), 2016, Head Office and Regional Offices, viewed 10 February 2016, from http://www.sassa.gov.za/index.php/contact-us/ head-office-and-regional-contacts

Stanleigh, M., 2016, 'Corporate strategy', viewed 05 February 2016, from http://www. reliableplant.com/Read/112/corporate-strategy

Stoner, J.A.F., 1982, Management, Prentice-Hall, New York.

Struwig, F.W. \& Stead, G.B., 2001, Planning, designing and reporting research, Maskew Miller Longman, Cape Town.

Sylvie, G. \& Witherspoon, P.D., 2002, Time, change and the American Newspaper, Lawrence Erlbaum, Mahwah, NJ.

Thomson, A.A. \& Strickland, A.J., 1998, Strategic management: Concepts and cases, Irwin McGraw-Hill, Boston, MA.

Van der Spuy, M.M., 2008, 'The development of the strategic management for a relationship model', MA dissertation, University of Pretoria, Pretoria.

Van der Waldt, G., 2001, 'Establishing a management by projects approach for service delivery', Journal for Public Administration 36(4), 296-311.

Van der Waldt, G., 2007, 'Project management: A new services delivery paradigm', Koers 72(2), 1-22. http://dx.doi.org/10.4102/koers.v72i2.201

Van der Waldt, G., 2009, 'Towards a project-based services delivery approach Uncovering organisational tensions', Administratio Publica 17(2), 36-53.

Van der Waldt, G., 2011, 'The uniqueness of public sector project management: A contextual perspective', Politeia. South African Journal for Political Science and Public Administration 30(2), 67-88.

Van der Waldt, G., 2014, 'Public Administration teaching and interdisciplinarity: Considering the consequences', Teaching Public Administration 32(2), 169-193. http://dx.doi.org/10.1177/0144739414523285

Van der Waldt, G. \& Fox, W., 2015, A guide to project management, 2nd edn., Juta, Cape Town.

Van der Waldt, G. \& Knipe, A., 1998, Project management for strategic change and upliftment, Thomson, Johannesburg.

Welman, C., Kruger, F. \& Mitchell, B., 2005, Research methodology, 3rd edn., Oxford University Press, Johannesburg.

Westcott, R.T., 2006, The certified manager of quality/organisational excellence handbook, 3rd edn., ASQ Quality Press, Milwaukee, WI.

Wheelen, T.L. \& Hunger, D.J., 1992, The strategic management and business policy, Addison-Wesley, New York.

Yin, R.K., 2012, Applications of case study research, 3rd edn., Sage, San Francisco, CA.

Zhang, L., 2010, 'Quality management in the small business environment of South Africa', in CPUT Theses \& Dissertations, paper 304, viewed 10 January 2016, from http://dk.cput.ac.za/cgi/viewcontent.cgi?article=1313\&context=td_cput 